University of Nebraska - Lincoln

DigitalCommons@University of Nebraska - Lincoln

\title{
Development Of A Quantitative Pasture Phosphorus Management Tool Using The Swat Model
}

\author{
Michael J. White \\ USDA-ARS Grassland, Soil, and Water Research Laboratory, mike.white@ars.usda.gov \\ Daniel E. Storm \\ Oklahoma State University \\ Michael D. Smolen \\ Oklahoma State University \\ Hailin Zhang \\ Oklahoma State University
}

Follow this and additional works at: https://digitalcommons.unl.edu/usdaarsfacpub

Part of the Agricultural Science Commons

White, Michael J.; Storm, Daniel E.; Smolen, Michael D.; and Zhang, Hailin, "Development Of A Quantitative Pasture Phosphorus Management Tool Using The Swat Model" (2009). Publications from USDA-ARS / UNL Faculty. 1068.

https://digitalcommons.unl.edu/usdaarsfacpub/1068

This Article is brought to you for free and open access by the U.S. Department of Agriculture: Agricultural Research Service, Lincoln, Nebraska at DigitalCommons@University of Nebraska - Lincoln. It has been accepted for inclusion in Publications from USDA-ARS / UNL Faculty by an authorized administrator of DigitalCommons@University of Nebraska - Lincoln. 


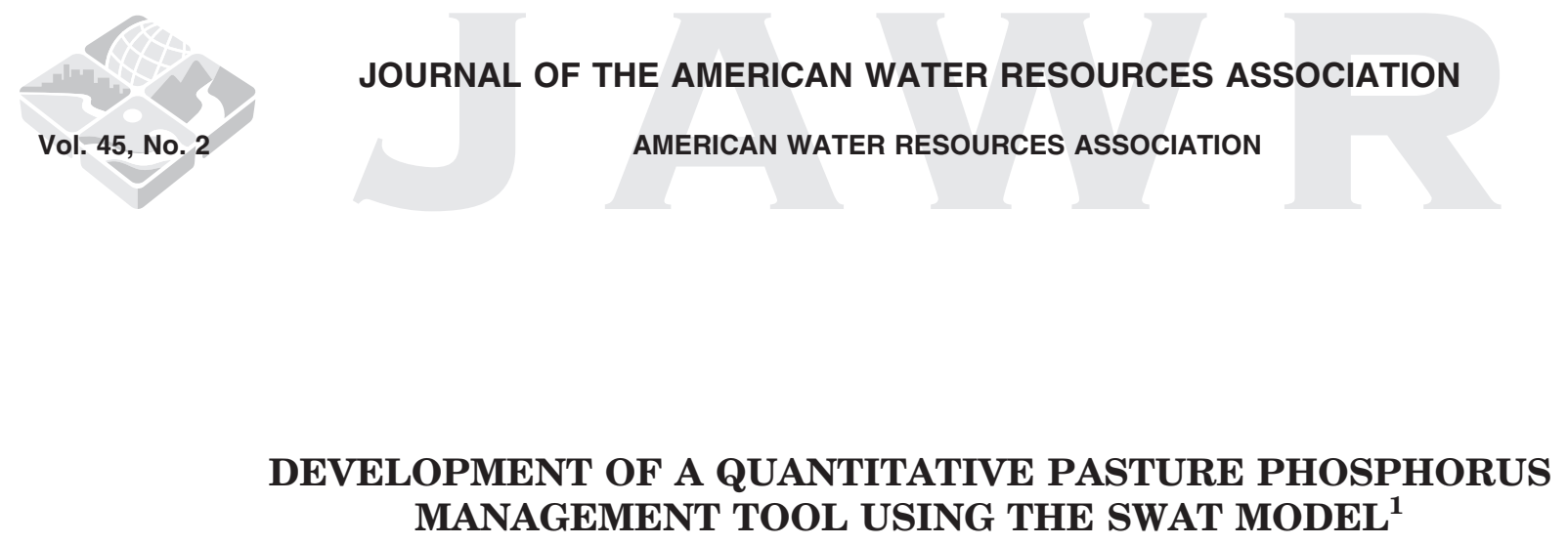

Michael J. White, Daniel E. Storm, Michael D. Smolen, and Hailin Zhang ${ }^{2}$

\begin{abstract}
Assessment tools to evaluate phosphorus loss from agricultural lands allow conservation planners to evaluate the impact of management decisions on water quality. Available tools to predict phosphorus loss from agricultural fields are either: (1) qualitative indices with limited applicability to address offsite water quality standards, or (2) models which are prohibitively complex for application by most conservation planners. The purpose of this research was to develop a simple interface for a comprehensive hydrologic/water quality model to allow its usage by farmers and conservation planners. The Pasture Phosphorus Management (PPM) Calculator was developed to predict average annual phosphorus (P) losses from pastures under a variety of field conditions and management options. PPM Calculator is a vastly simplified interface for the Soil and Water Assessment Tool (SWAT) model that requires no knowledge of SWAT by the user. PPM Calculator was validated using 33 months of data on four pasture fields in northwestern Arkansas. This tool has been extensively applied in the Lake Eucha/Spavinaw Basin in northeastern Oklahoma and northwestern Arkansas. PPM Calculator allows conservation planners to take advantage of the predictive capacity of a comprehensive hydrologic water quality model typically reserved for use by hydrologists and engineers. This research demonstrates the applicability of existing water quality models in the development of user friendly P management tools.
\end{abstract}

(KEY TERMS: SWAT; modeling; watershed management; nutrients; nonpoint source pollution; phosphorus management; phosphorus index; field scale.)

White, Michael J., Daniel E. Storm, Michael D. Smolen, and Hailin Zhang, 2009. Development of a Quantitative Pasture Phosphorus Management Tool Using the SWAT Model. Journal of the American Water Resources Association (JAWRA) 45(2):397-406. DOI: 10.1111/j.1752-1688.2008.00295.x

\section{JUSTIFICATION}

Phosphorus $(\mathrm{P})$ is an important nutrient in both aquatic and terrestrial systems. The over application of $\mathrm{P}$ fertilizers to agricultural fields may have a direct negative impact on the water quality of lakes, rivers, and streams. $\mathrm{P}$ concentration in surface waters is positively correlated with primary productivity (Schindler, 1978). Excess algal productivity may result in fish kills and undesirable water conditions for recreation and consumption. Although lakes, rivers, and streams differ in their response to anthropogenic $\mathrm{P}$, reducing the $\mathrm{P}$ concentration and/or load is often an effective strategy to control aquatic plant and algal growth because $\mathrm{P}$ is often the limiting

\footnotetext{
${ }^{1}$ Paper No. JAWRA-08-0027-P of the Journal of the American Water Resources Association (JAWRA). Received January 31, 2008; accepted August 22, 2008. (c) 2009 American Water Resources Association. Discussions are open until October 1, 2009.

${ }^{2}$ Respectively, Agricultural Engineer (White), USDA-ARS Grassland, Soil, and Water Research Laboratory, 808 East Blackland Road, Temple, Texas 76502; Professor (Storm, Smolen), Biosystems Engineering, Oklahoma State University, Stillwater, Oklahoma; and Professor (Zhang), Plant and Soil Sciences, Oklahoma State University, Stillwater, Oklahoma (E-Mail/White: mike.white@ars.usda.gov).
} 
nutrient (Tilman et al., 1982). Nutrient availability in lakes and reservoirs increases naturally over time through the process of eutrophication. Anthropogenic nutrient enrichment of these systems accelerates this natural aging process, significantly reducing the useful lifespan of lakes and reservoirs.

$P$ is found throughout the environment, but its concentration varies significantly. Industrial animal production by Concentrated Animal Feeding Operations (CAFOs) import large quantities of $\mathrm{P}$ in animal feed, but export little $\mathrm{P}$ in the products produced (Sharpley et al., 2003a). The majority of $\mathrm{P}$ consumed by animals is excreted in manures which are often applied as fertilizer on or near the farm. The economics of scale and transportation force CAFOs to locate near industrial animal processing and feed production facilities, resulting in regions with high CAFO densities and net $\mathrm{P}$ accumulation. Poultry production results in far greater $P$ accumulation at the farm level, as compared to crop or dairy production (Sharpley, 1999). One such region of concentrated poultry production is located in eastern Oklahoma and western Arkansas. The management of $\mathrm{P}$ at the farm, basin, and regional scales is needed to protect water quality.

One approach to $\mathrm{P}$ management at the farm scale is the use of a P Index. A P Index is an assessment tool used by planners and producers to assess the potential of $\mathrm{P}$ leaving a farm and traveling toward a water body (NRCS, 1994). A P Index is typically a qualitative tool that yields a categorical rating of $\mathrm{P}$ loss from a single site based on metrics representing field conditions and management options thought to influence P loss in runoff. Each factor is assigned a weight based on professional judgment and/or empirical relationships derived from local $\mathrm{P}$ loss studies. These individual weighted factors are combined into a single numerical $\mathrm{P}$ Index, which is interpreted into categories of $\mathrm{P}$ loss risk. These categories are then used to specify allowable application rates for animal manures and/or commercial fertilizers.

The P Index concept was developed by the United States Department of Agriculture (USDA) Natural Resource Conservation Service (NRCS) in the early 1990s (Lemunyon and Gilbert, 1993). At that time, USDA Agricultural Research Service (ARS) had at least 15 years vested in hydrologic/water quality model development. Comprehensive hydrologic/water quality models, such as the Agricultural Non-Point Source model (AGNPS) (Young et al., 1989) and Erosion Productivity Impact Calculator (EPIC) (Williams, 1990), were already fully capable of predicting P loss from agricultural fields. However, $\mathrm{P}$ Indices and comprehensive hydrologic models had two distinctly separate purposes and sets of users; P Indices provided simple qualitative assessment of $\mathrm{P}$ loss for conservation planners, and models provided quantitative assessment of multiple constituents for use by more specialized model operators.

$P$ Indices were neither initially developed to be quantitative predictors of $\mathrm{P}$ loss (Lemunyon and Gilbert, 1993), nor intended to be used as a regulatory tool (NRCS, 1994). The role of P Indices has been expanded to aid in the development of Comprehensive Nutrient Management Plans (CNMPs) for NRCS Conservation Practice Standard for Nutrient Management Code 590 and to specify manure application rates in watersheds with impaired or threatened surface waters. To meet the 590 Standard, each state must develop a $\mathrm{P}$ management strategy; most states have adopted the P Index approach (Sharpley et al., 2003b). P loss and transport processes are complex (Sharpley et al., 2002). With the increased need for accuracy to meet a regulatory or a specific water quality goal, P Indices have become increasingly refined and complex. The flexible framework of the $\mathrm{P}$ Index approach readily allows the incorporation of new science to improve prediction accuracy. The majority of $\mathrm{P}$ Indices incorporate predictions from other models, such as the Revised Universal Soil Loss Equation (RUSLE), to improve prediction of particulate P loss (Sharpley et al., 2003b).

Some P Indices have demonstrated a high correlation with measured $\mathrm{P}$ yields (Eghball and Gilley, 2001; Sharpley et al., 2001; Harmel et al., 2005), indicating that these indices may have the potential to predict quantities of $\mathrm{P}$ loss even though they were developed as qualitative tools. The ability of some $\mathrm{P}$ Indices to function as quantitative $\mathrm{P}$ models has further blurred the line between a $\mathrm{P}$ Index and a $\mathrm{P}$ model. Current comprehensive hydrologic/water quality models, like the Soil and Water Assessment Tool (SWAT) (Arnold et al., 1998), have a full $\mathrm{P}$ submodel, which is process-based and attempts to mimic the complete $\mathrm{P}$ cycle. These models also evolve as new science is developed and incorporated.

Existing hydrologic/water quality models, such as SWAT, have several advantages over qualitative $\mathrm{P}$ Indices. First, SWAT can make quantitative predictions of site-specific P loss at both the field and basin scales. $\mathrm{P}$ loss is a basin-scale problem which requires management at the field level. P Indices are only a piece of the solution and should be applied in the framework of basin-scale water quality objectives. Qualitative P Indices are categorical, which make it difficult or impossible to interpret them in the context of numeric water quality standards or goals. Quantitative P Indices have been applied at the basin scale (Birr and Mulla, 2001). However, they do not consider larger scale water quality processes and nonagricultural contributions, which are necessary to evaluate downstream water quality impacts. The 
SWAT model is applicable to both field-scale $\mathrm{P}$ loss and basin-scale water quality assessment. The accuracy of SWAT at the field scale may be further enhanced by calibrating SWAT at the basin scale using widely available water quality data and applying that calibration at the field scale where little or no measured $\mathrm{P}$ loss data are available.

The second advantage of hydrologic/water quality models is their process-based framework, which is capable of accurately predicting $\mathrm{P}$ load reductions from diverse conditions under various management scenarios, including Best Management Practices (BMPs). Traditional P Index components are, at best, developed empirically using only locally measured $\mathrm{P}$ loss data, resulting in a high degree of regional or local specificity. Under these conditions they may perform well, but under different conditions performance may decline significantly (Harmel et al., 2005). SWAT is the product of over 30 years of research and has been validated and tested extensively both domestically and internationally (Gassman et al., 2007). Finally, hydrologic models like SWAT can make predictions of not only $\mathrm{P}$, but also other important environmental concerns like nitrogen, sediment, pesticides, and bacteria. Phosphorous is only one of many widespread water quality concerns; the U.S. Environmental Protection Agency (USEPA) lists more waters impaired for bacteria $(14.2 \%)$ and sediment (9.9\%) than for nutrients (8.8\%) (USEPA, 2008). In the future, CNMP developers may have to consider multiple pollutants to develop a single farm plan.

Basin-scale models like SWAT have one primary weakness, they are complex. These models require a great deal of specialized knowledge and extensive data, which are not readily available to $\mathrm{P}$ Index users. Conservation planners and farmers/ranchers require a simpler tool (Veith et al., 2005). Interfaces available for SWAT are very complex, as they are designed to represent a large basin in detail and offer extensive configuration and management options. If the scale is reduced to a single field and the options restricted, data requirements are comparable to existing P Indices. A specialized interface can translate a relatively simple set of instructions from the user to the complex set of input parameters required by the SWAT model. The purpose of this research was to develop such an interface to allow the SWAT model to be used as a P-management tool with complexity comparable to that of a traditional $\mathrm{P}$ Index. This interface can make edge-of-field $\mathrm{P}$ load predictions using the power of a quantitative, process-based hydrologic/water quality model. This tool was developed specifically for pastures in the Lake Eucha/Spavinaw Basin, located in northeast Oklahoma and northwest Arkansas (Figure 1), but the concept can be applied to other watersheds, or regions.

\section{PPM CALCULATOR DEVELOPMENT}

\section{Applicability and Background}

The Pasture Phosphorus Management (PPM) Calculator is a quantitative $\mathrm{P}$ assessment tool based on the SWAT model to make $\mathrm{P}$ loss predictions for a single pasture field (White et al., 2003). PPM Calculator was developed specifically for application in the Lake Eucha/Spavinaw Basin (Figure 1). This basin encompasses 101,000 ha, $65 \%$ of which lies in northeast Oklahoma with the remainder in northwest Arkansas. These lakes, Eucha and Spavinaw, supply drinking water to the City of Tulsa, Oklahoma, and surrounding municipalities, and have suffered degraded water quality due to excessive algal production in recent years (Haggard et al., 2001). The Lake Eucha/Spavinaw Basin is heavily involved in poultry production (Popova et al., 2006). Most of the manure and bedding from poultry production, referred to as poultry litter, is utilized locally as fertilizer for pastures. The result is greatly improved productivity of grazing and forage production areas, but increased $\mathrm{P}$ loss to the surface waters of the region. Assuming the $83,000 \mathrm{Mg}$ of poultry litter produced in 2002 was uniformly applied on all pastures in the basin, $25 \mathrm{~kg} / \mathrm{ha}$ of $\mathrm{P}$ was applied annually (Storm et al., 2002). The poultry industry has operated in the area for approximately 40 years; many fields have very high soil-test $\mathrm{P}$ levels (Storm et al., 2002). PPM Calculator was developed to evaluate the edge-of-field P loss arising

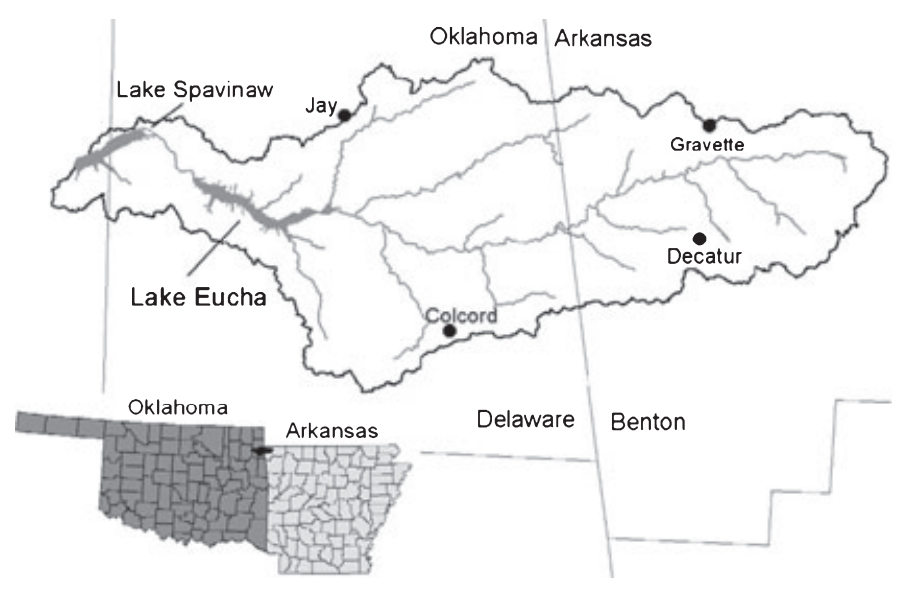

FIGURE 1. Lake Eucha/Spavinaw Basin Location. 
from various management scenarios, such as poultry litter application and elevated soil-test $\mathrm{P}$ levels.

\section{PPM Calculator/SWAT Linkage}

PPM Calculator is a simplified interface for the SWAT 2000 model designed to be easy to use; the user does not see or directly interact with the SWAT model. All PPM Calculator user inputs are located in a single dialog; the user interface is shown in Figure 2. Data entered by the user are transformed into SWAT model input files and the model is executed in the background. SWAT results are translated and summarized, and then presented to the user. A conceptual diagram of PPM Calculator is given in Figure 3. To limit complexity, PPM Calculator uses only the field-scale routines of the SWAT model. When used for basin-scale assessment, SWAT subdivides a basin into subbasins which are further partitioned into Hydrologic Response Units (HRUs). A basin-scale SWAT model may contain thousands of HRUs; PPM Calculator uses a single HRU to represent a single pasture. SWAT model inputs for this HRU are generated from relatively simple and readily available data supplied by the user. SWAT inputs, like biomass consumption, trampling, manure production, and nutrient content (all required to simulate grazing), are generated from more familiar terms like stocking rate. As a basin-scale model, SWAT has many input parameters, but if used to simulate a single pasture, only a small number of relatively simple inputs are required.

PPM Calculator requires a variety of user data, most of which are also needed for traditional P Indices. A list of required PPM Calculator inputs is given in Table 1; other inputs are used for record keeping. These data are transformed and passed from PPM Calculator to SWAT within the HRU Properties (.hru), Soil Chemistry (.chm), Soil Properties (.sol), and Management Operations (.mgt) SWAT input files. Other SWAT input files are not altered by the PPM Calculator at runtime; parameters in these files are primarily SWAT defaults.

Some SWAT parameters were fixed to simplify the application of SWAT within PPM Calculator. SWAT uses the Modified Universal Soil Loss Equation (MUSLE) (Williams, 1975) to predict sediment delivery. MUSLE is sensitive to drainage area and other topographical characteristics which influence peak flow. These topographical characteristics pertain to watersheds not fields. Depending on the scaling perspective, a single field may consist of several smaller watersheds or a single watershed may span many fields. These topographical characteristics are fixed in PPM Calculator because the information to

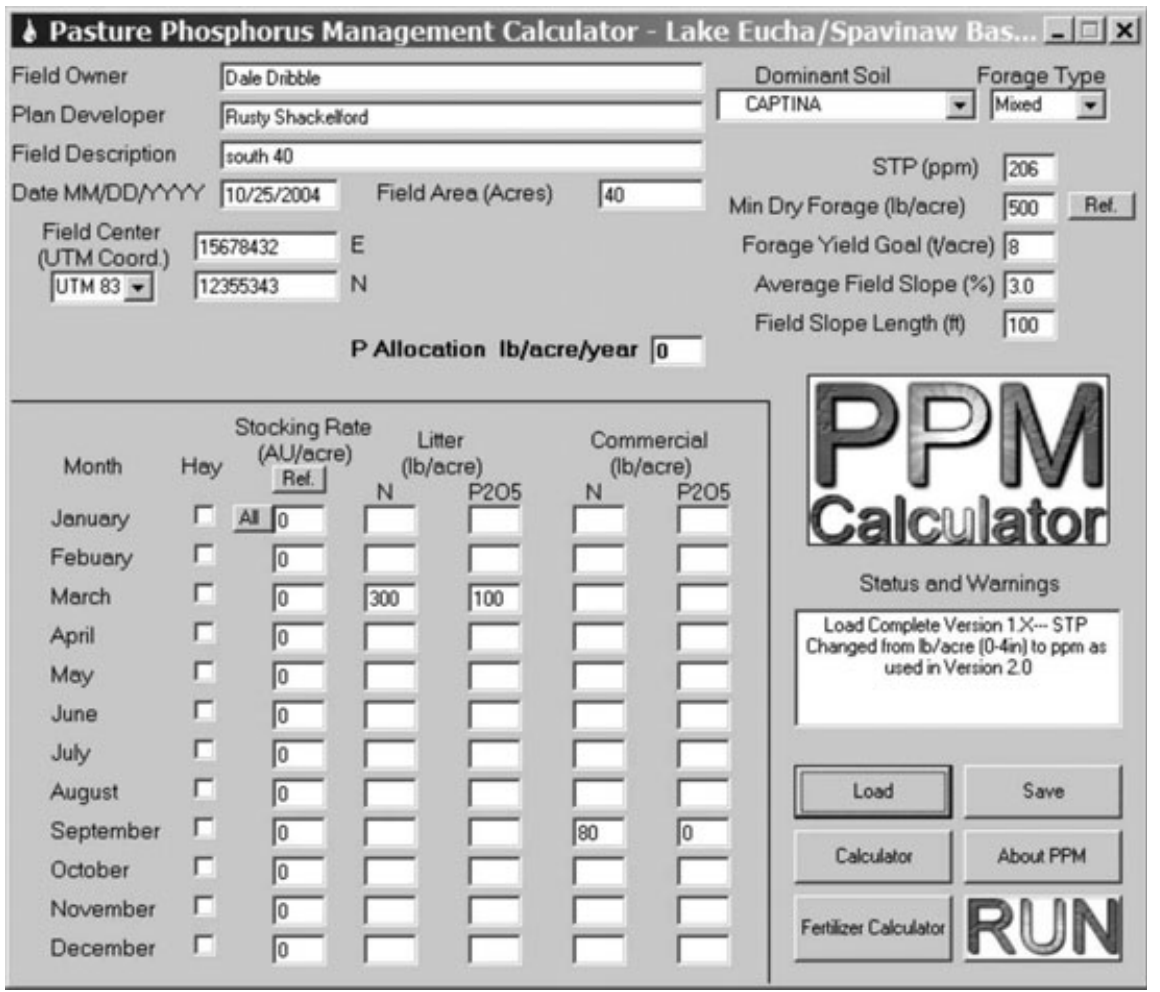

FIGURE 2. PPM Calculator Interface (Version 2.0). 


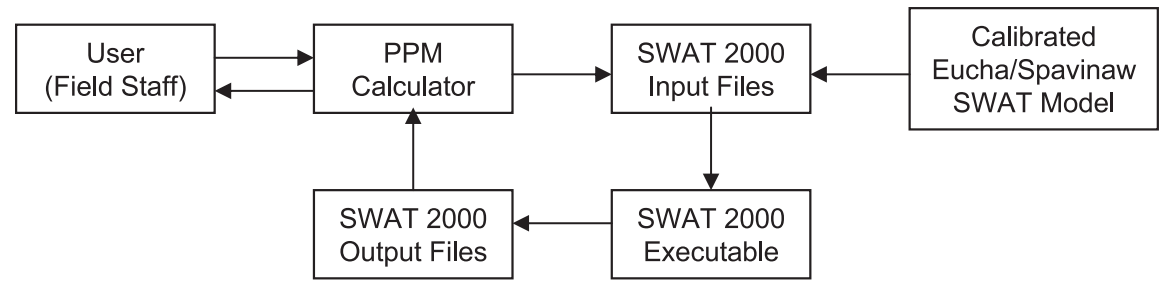

FIGURE 3. PPM Calculator Conceptual Diagram.

TABLE 1. PPM Calculator Inputs Used in the SWAT 2000 Model.

\begin{tabular}{|c|c|}
\hline User Input & Description \\
\hline Soil type & Dominant soil, select one of 35 local soils \\
\hline Forage type & $\begin{array}{l}\text { Dominant forage type, specify warm, } \\
\text { cool, or mixed forage }\end{array}$ \\
\hline STP & Mehlich III soil test phosphorus (STP) \\
\hline $\begin{array}{l}\text { Minimum } \\
\text { dry forage }\end{array}$ & $\begin{array}{l}\text { Minimum dry forage during the growing } \\
\text { season. Grazing is suspended by SWAT } \\
\text { when this level is reached }\end{array}$ \\
\hline Field slope & Average field slope in percent \\
\hline Slope length & $\begin{array}{l}\text { Revised universal soil loss equation slope } \\
\text { length }\end{array}$ \\
\hline Hay & Select months when hay is cut \\
\hline Stocking rate & $\begin{array}{l}\text { Number of animal units per acre grazed } \\
\text { each month }\end{array}$ \\
\hline Poultry litter $\mathrm{N}$ & $\begin{array}{l}\text { Nitrogen (as N) applied as poultry litter } \\
\text { each month }\end{array}$ \\
\hline Poultry litter P & $\begin{array}{l}\text { Phosphorus applied as poultry litter each } \\
\text { month }\end{array}$ \\
\hline Commercial N & $\begin{array}{l}\text { Nitrogen (as N) applied as commercial } \\
\text { fertilizer each month }\end{array}$ \\
\hline Commercial P & $\begin{array}{l}\text { Phosphorus applied as commercial } \\
\text { fertilizer each month }\end{array}$ \\
\hline
\end{tabular}

parameterize this aspect of SWAT is not readily available to conservation planners. More easily measured topographical parameters, such as Field Slope and Slope Length, are required inputs and are directly used by SWAT.

Soil-test $\mathrm{P}$ is not a direct SWAT input parameter, although it is an important factor in the loss of $\mathrm{P}$ from pastures. PPM Calculator incorporates soil-test $\mathrm{P}$ into SWAT by altering the quantity of $\mathrm{P}$ in SWAT's soil Labile pool. SWAT contains three conceptual mineral P pools: Active, Stable, and Labile or soluble. We assumed that a Mehlich III extractant can dissolve $\mathrm{P}$ roughly equal to that contained in the Active and Labile pools. In SWAT Soil, Labile P represents $\mathrm{P}$ in the soil solution or in very rapid equilibrium with it. The Active pool is in fairly rapid equilibrium (i.e., days) with the Labile pool, and is by default 1.5 times larger. PPM Calculator sets the soil Labile P in the first three soil layers to the soil-test $\mathrm{P}$ in $\mathrm{mg} / \mathrm{kg}$ divided by 2.5 .

Several PPM Calculator user inputs describe field management; each of these is transformed into SWAT parameters in the management (.mgt) files. The Minimum Dry Forage in PPM Calculator is directly used as SWAT's Minimum Dry Biomass (BIOMIN). BIOMIN is the minimum dry above ground biomass at which grazing is permitted. Another important SWAT input, Curve Number, is based on grazing, Minimum Dry Forage, and Hydrologic Soil Group (Table 2). To eliminate discontinuities, Curve Number is linearly interpolated based on user-specified Minimum Dry Forage.

Several field management inputs, such as hay cutting, fertilization, and stocking rate, may be specified monthly in PPM Calculator to account for seasonal changes in weather and forage production. These are also accounted for in SWAT's Management File (.mgt) as management operations. A planting operation in the management file starts the growing season with the forage type specified by the user. This planting operation is scheduled for January 1, but forage growth will not occur until temperatures are suitable. Cool season and mixed forage will generally have earlier growth than warm season forage. Fertilizer applications can also be specified by month. If poultry litter or commercial fertilizer is applied the operation is scheduled for the first day of the month. Haying is allowed from June to September for warm season forages and June and July for cool season grasses. Hay operations were assumed to cut $90 \%$ of the above ground forage with $90 \%$ of cut forage removed from the field. Cut forage not removed from the field is converted to residue. These harvest efficiency parameters

TABLE 2. Curve Number Used in SWAT 2000 by PPM Calculator Based on Grazing, Minimum Dry Forage, and Hydrologic Soil Group.

\begin{tabular}{lllll}
\hline & \multicolumn{4}{c}{$\begin{array}{c}\text { Hydrologic Soil } \\
\text { Group }\end{array}$} \\
\cline { 2 - 5 } Pasture Activity and Condition & A & B & C & D \\
\hline Grazing and minimum dry forage $<400 \mathrm{~kg} / \mathrm{ha}$ & 68 & 79 & 86 & 89 \\
Grazing and minimum dry forage $=650 \mathrm{~kg} / \mathrm{ha}$ & 49 & 69 & 79 & 84 \\
Grazing and minimum dry forage $>900 \mathrm{~kg} / \mathrm{ha}$ & 39 & 61 & 74 & 80 \\
No grazing & 30 & 58 & 71 & 78 \\
\hline
\end{tabular}

Note: To eliminate discontinuities, Curve Number was linearly interpolated based on user specified Minimum Dry Forage. 
were SWAT defaults. SWAT simulates cattle grazing as the daily removal of biomass with a corresponding deposition of manure. PPM Calculator uses user specified stocking rates by month to estimate forage usage and manure production. The amount of forage consumed by an animal unit is $11.3 \mathrm{~kg}$ dry matter/day with an additional $2.8 \mathrm{~kg}$ dry matter/day being trampled (Redmon and Bidwell, 1997). Each animal unit produces $3.6 \mathrm{~kg}$ of manure daily (ASAE, 1995). If at any time the amount of available forage falls below the Minimum Dry Forage, SWAT suspends grazing until more forage growth occurs.

\section{Lake Eucha/Spavinaw Basin Calibration Parameters}

PPM Calculator utilizes hydrologic parameters ported from a calibrated Lake Eucha/Spavinaw Basin SWAT 2000 model (Storm et al., 2002) to improve the accuracy in predicting off-site impact. It should be noted that the use of SWAT parameters calibrated at the basin scale does not imply calibration at the field or HRU level. The use of these hydrologic parameters should, however, better represent local conditions than SWAT default values. Parameters/data taken from the calibrated Lake Eucha/Spavinaw Basin model are given in White et al. (2003). In addition, due to the lack of instream nutrient processes in the original Lake Eucha/Spavinaw Basin SWAT Model, nutrient parameters in PPM Calculator are SWAT defaults. Therefore, PPM Calculator should be considered an uncalibrated model.

\section{Simulation}

Once all user data are entered and "Run" is pressed, the inputs are checked to ensure that they are numeric, positive, and in the acceptable range. All program files are inspected to detect modifications or corruption, which may invalidate predictions. The SWAT model is then automatically executed in the background and performs a 15-year simulation using historical daily weather data collected in the Lake Eucha/Spavinaw Basin. All the information entered by the user is listed in the output, along with monthly and annual precipitation, runoff, sediment and total $\mathrm{P}$ edge-of-field losses.

\section{VALIDATION}

PPM Calculator was validated for runoff, sediment, and soluble and total $\mathrm{P}$ predictions. Validation is an effort to evaluate prediction uncertainty by testing model predictions against measured data not used in the development of the model. Calibration is the process of adjusting a model's parameters such that its predictions better match measured data. No calibration was performed with PPM Calculator, other than the inclusion of hydrologic parameters calibrated previously at the basin level from Storm et al. (2002). The PPM Calculator was validated using 33 months of data on four pasture fields located 12 miles west of Fayetteville, Arkansas (Edwards et al., 1994). These data were collected close to, but outside the Lake Eucha/Spavinaw Basin. Conditions at the study sites were very similar to those within the Lake Eucha/Spavinaw Basin. Weather data collected near the study sites were used in PPM Calculator for the validation simulations. Data were collected and reported by Edwards et al. $(1994,1996)$ for the period October 1991 to April 1994. The study monitored four pasture fields under natural rainfall with elevated soil-test $\mathrm{P}$ due to long-term application of poultry litter. All four fields received poultry litter prior to the monitoring period. During the monitoring period Fields $\mathrm{A}$ and $\mathrm{C}$ received 13 and $12 \mathrm{Mg} / \mathrm{ha} /$ year poultry litter, respectively, and fields $\mathrm{B}$ and $\mathrm{D}$ received 95 and $84 \mathrm{~kg} / \mathrm{ha} /$ year commercial nitrogen (no poultry litter), respectively. Fields were grazed at stocking densities of $1.1,1.2,0.80$, and $0.36 \mathrm{AU} /$ ha for fields A, B, C, and D, respectively. An average of 47 runoff events per field occurred during the study (Edwards et al., 1996); event statistics are given in Table 3. Event mean nutrient and total suspended solids concentrations were highly variable with coefficients of variation ranging from 0.39 to 2.26.

Comparisons between observed $\mathrm{P}$ loss and PPM Calculator predictions are given in Table 4 on an average annual basis. Comparison of total $\mathrm{P}$ loads yielded relative errors from $-12 \%$ to $66 \%$, with an average of $33 \%$. Although PPM Calculator is intended to use average annual predictions, comparisons of total P load on a monthly basis are given in Figure 4

TABLE 3. Observed Event Mean Surface Runoff Volume, Soluble and Total Phosphorus and Total Suspended Solids Collected by Edwards et al. (1994) for the Period October 1991 to April 1994.

\begin{tabular}{lrrrr}
\hline & \multicolumn{4}{c}{ Site } \\
\cline { 2 - 5 } Parameter & A & B & C & D \\
\hline \multirow{4}{*}{ Runoff events } & 50 & 43 & 48 & 48 \\
Samples & 206 & 176 & 226 & 266 \\
Surface runoff & \multicolumn{5}{c}{ Coefficient of Variation } \\
Total phosphorus & 0.43 & 0.52 & 0.62 & 0.56 \\
Soluble phosphorus & 0.74 & 0.57 & 1.26 & 0.49 \\
Total suspended solids & 0.86 & 0.47 & 1.25 & 0.39 \\
& 1.06 & 1.63 & 1.20 & 2.26 \\
\hline
\end{tabular}


Development of a Quantitative Pasture Phosphorus Management Tool Using the SWat Model

TABLE 4. Pasture Phosphorus Management (PPM) Calculator Validation Results Using Data From Edwards et al. (1994) for the Period October 1991 to April 1994.

\begin{tabular}{|c|c|c|c|c|c|}
\hline Constituent & Site & Units & Observed & Predicted & $\begin{array}{c}\text { Relative } \\
\text { Error } \\
(\%)\end{array}$ \\
\hline \multirow{4}{*}{$\begin{array}{r}\text { Surface } \\
\text { runoff }\end{array}$} & $\mathrm{A}$ & $\mathrm{mm} /$ year & 210 & 170 & 19 \\
\hline & B & & 45 & 80 & -76 \\
\hline & $\mathrm{C}$ & & 71 & 85 & -20 \\
\hline & $\mathrm{D}$ & & 190 & 89 & 53 \\
\hline \multirow{8}{*}{$\begin{array}{l}\text { Total } \\
\text { phosphorus }\end{array}$} & $\mathrm{A}$ & $\mathrm{mg} / 1$ & 2.2 & 3.4 & -54 \\
\hline & B & & 1.7 & 0.7 & 60 \\
\hline & $\mathrm{C}$ & & 2.8 & 2.6 & 6 \\
\hline & $\mathrm{D}$ & & 1.4 & 1.0 & 28 \\
\hline & $\mathrm{A}$ & $\mathrm{kg} / \mathrm{ha} /$ year & 4.6 & 5.7 & -25 \\
\hline & $\mathrm{B}$ & & 0.77 & 0.55 & 29 \\
\hline & $\mathrm{C}$ & & 2.0 & 2.2 & -12 \\
\hline & $\mathrm{D}$ & & 2.7 & 0.91 & 66 \\
\hline \multirow{8}{*}{$\begin{array}{l}\text { Soluble } \\
\text { phosphorus }\end{array}$} & $\mathrm{A}$ & $\mathrm{mg} / \mathrm{l}$ & 2.1 & 2.5 & -20 \\
\hline & B & & 1.5 & 0.5 & 66 \\
\hline & $\mathrm{C}$ & & 2.2 & 2.1 & 4 \\
\hline & $\mathrm{D}$ & & 1.4 & 0.6 & 60 \\
\hline & $\mathrm{A}$ & $\mathrm{kg} / \mathrm{ha} /$ year & 4.3 & 4.3 & 2 \\
\hline & $\mathrm{B}$ & & 0.66 & 0.39 & 41 \\
\hline & $\mathrm{C}$ & & 1.6 & 1.8 & -15 \\
\hline & $\mathrm{D}$ & & 2.7 & 0.50 & 81 \\
\hline \multirow{8}{*}{$\begin{array}{l}\text { Sediment } \\
\text { yield }\end{array}$} & $\mathrm{A}$ & $\mathrm{mg} / \mathrm{l}$ & 37 & 92 & -146 \\
\hline & $\mathrm{B}$ & & 65 & 70 & -8 \\
\hline & $\mathrm{C}$ & & 96 & 58 & 40 \\
\hline & $\mathrm{D}$ & & 63 & 114 & -81 \\
\hline & $\mathrm{A}$ & $\mathrm{kg} / \mathrm{ha} /$ year & 78 & 150 & -99 \\
\hline & $\mathrm{B}$ & & 29 & 56 & -90 \\
\hline & $\mathrm{C}$ & & 68 & 49 & 28 \\
\hline & $\mathrm{D}$ & & 120 & 100 & 14 \\
\hline
\end{tabular}

to illustrate seasonal trends. Although monthly total $\mathrm{P}$ loads may differ in magnitude, especially at Site D, both observed and predicted losses generally follow the same trends. Coefficients of determination between monthly observed and predicted total $\mathrm{P}$ load for sites which received poultry litter $(\mathrm{A}=0.58$, $\mathrm{C}=0.81$ ) were better than sites which received only commercial nitrogen fertilizer $(\mathrm{B}=0.21, \mathrm{D}=0.23)$. Relative errors in sediment yield ranged from $28 \%$ to $-99 \%$. Although this error was large on a relative basis, sediment yields from these fields were very small and the maximum overprediction was $72 \mathrm{~kg} / \mathrm{ha} /$ year. Runoff volume relative errors ranged from $53 \%$ to $-76 \%$. PPM Calculator overpredicted runoff volume from cherty/gravelly soils (B and C) and underpredicted runoff from loamy soils (A and D). Based on our past experiences using SWAT in the same ecoregion, the SWAT model generally overpredicts runoff volume from cherty and gravelly soils in the area. Therefore, the soils database included in SWAT may not properly represent these soils, which may help explain some of these differences.

PPM Calculator performed better on fields which received poultry litter (A, C) than those which received only commercial nitrogen $(\mathrm{B}, \mathrm{D})$, and generally underpredicted total $\mathrm{P}$ loads on fields $\mathrm{B}$ and $\mathrm{D}$. PPM Calculator underpredicted soluble $\mathrm{P}$ by $20 \%$ and $4 \%$ on poultry littered fields (A, C) and underpredicted by $66 \%$ and $60 \%$ on commercial nitrogen only fields (B, D). Model performance for total and soluble $\mathrm{P}$ loads at poultry littered sites was comparable to SWAT watershed-scale performance reported by other researchers. White and Chaubey (2005) reported relative errors of $10.6 \%$ to $-51.2 \%$ on an annual basis and monthly coefficients of determination of 0.58 to 0.82 for SWAT predicted total P load from basins in northwestern Arkansas. One likely explanation for poor performance on sites which received only commercial nitrogen during the monitoring period $(\mathrm{B}, \mathrm{D})$ is the application of poultry litter on all sites just prior to monitoring, which is not represented well by PPM Calculator. PPM Calculator considers only the effect of elevated soil-test $P$ resulting from past poultry litter applications, but poultry litter also influences soil-P distribution and solubility for many months after application (Pierson et al., 2001; Franzluebbers et al., 2002).

Sites B and D experienced significant decreases in runoff soluble $\mathrm{P}$ concentration and soil-test $\mathrm{P}$ during the monitoring period (Edwards et al., 1996). It is likely that at some point a new pseudo-steady state would be reached and soil-test $\mathrm{P}$ and soluble $\mathrm{P}$ losses would be much more stable. Franzluebbers et al. (2002) found that the application of poultry litter significantly altered the depth distribution of extractable $\mathrm{P}$ in the soil profile, resulting in a P-enriched surface layer. Pierson et al. (2001) found elevated soluble P losses for 19 months following poultry litter application. Although these effects are accounted for in the SWAT P submodel, they were not included in PPM Calculator because including management and fertilization from prior years would complicate the interface and compromise the tool's utility for conservation planners. Regardless of these limitations, these data from Edwards et al. (1994) were the only fieldscale $\mathrm{P}$ monitoring data available in the region. In addition, the purpose of PPM Calculator is to predict the long-term average annual $\mathrm{P}$ loss, and thus for this purpose prior field management effects, which diminish with time, are less important. The overall performance of the PPM Calculator was considered acceptable for use as a P planning tool.

\section{DISCUSSION AND CONCLUSIONS}

Comprehensive hydrologic/water quality models have been available before the introduction of $\mathrm{P}$ 

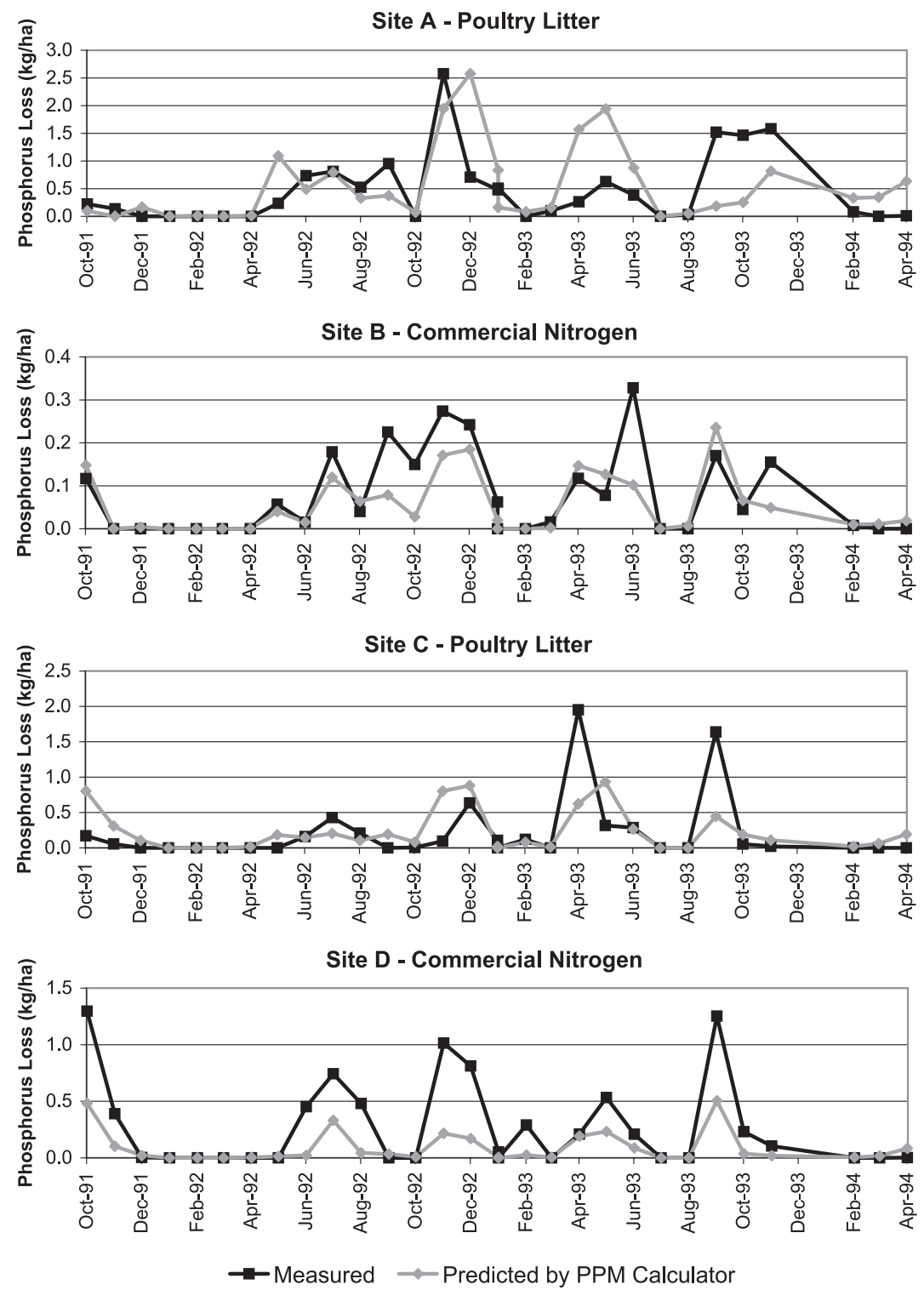

FIGURE 4. Monthly Measured Phosphorus Loss (Edwards et al., 1994) and PPM Calculator Predictions for Four Pasture Fields in Northwestern Arkansas.

Indices. P Indices were developed as alternatives to these models with an emphasis on simplicity and ease of use. However, the cost of this simplicity is qualitative scaling, and limited applicability under diverse conditions. $\mathrm{P}$ loss is a function of many factors; while it is certainly possible to over-complicate a model with irrelevant processes and parameters, a certain level of complexity is required to accurately predict $\mathrm{P}$ loss under a wide range of conditions. This research focuses on the simplification of an existing well tested and validated process-based model that can easily be used by conservation planners and linked to basin-scale water quality objectives or numeric water quality standards.
PPM Calculator demonstrates that a complex model like SWAT can be the engine for an easy to use P management tool. The PPM Calculator has been applied to each pasture in the Lake Eucha/Spavinaw Basin receiving poultry litter from 2004 to 2007 by conservation planners to evaluate the edge-of-field $\mathrm{P}$ loss. No difficulties have been reported from the application of this model-based assessment tool. Though the validation of PPM Calculator was limited, its performance was acceptable given the limitations of the validation dataset. The performance of models continually improves as our understanding of $\mathrm{P}$ dynamics evolves. Much of the information accumulated by $\mathrm{P}$ researchers is yet to 
be included in models like SWAT and EPIC. Advancements in $\mathrm{P}$ and manure routines have been developed (Vadas et al., 2006, 2007), but are not yet included in mainstream models. A new version of PPM Calculator has been developed which includes a number of these improvements. The validation was expanded from 11 field-years to 283 field-years of data collected across the southern United States. Applicability was expanded to cover the entire state of Oklahoma, and support for cultivated crops and additional BMPs was included (White, 2007). In addition, the SWAT P submodel was improved to allow more accurate $\mathrm{P}$ loss predictions.

Although quantitative models have many advantages over qualitative indices, there are a number of important considerations. First, quantitative models make no determination of how much $\mathrm{P}$ loss is acceptable; yet this limit is required for use as a regulatory tool. The development of acceptable edge-of-field $\mathrm{P}$ loss limits is not an easy task. The availability of numeric $\mathrm{P}$ standards may simplify the process; yet determining appropriate and fair limits within mixed landuse basins remains problematic. Qualitative P Indices include qualitative limits, which are generally selected based on professional judgment. Whether quantitative or qualitative, these limits directly influence which fields are eligible to receive animal manures and represent a policy decision and should be watershed specific. Second, all model predictions contain error; the range of this error is unknown without extensive validation. Models are typically an estimation tool and not a measurement device, and thus errors in model predictions should be expected. Third, the widespread use of quantitative $\mathrm{P}$ loss tools may result in an increased exposure to litigation. Models can predict the actual amount of $\mathrm{P}$ loss by a landowner. Other methods can also be used to estimate the environmental damage resulting from a quantity of P loss (Ancev et al., 2006). It is conceivable that this combination could be used to assess monetary damages in a court of law. The challenges arising from the use of a quantitative model for $\mathrm{P}$ management are a consequence of the additional information they provide.

Models will almost certainly play an important role in the future of field level P management. The ability of process-based models to predict $\mathrm{P}$ loss under diverse conditions may pave the way to regional or national $\mathrm{P}$ management tools. Current $\mathrm{P}$ Indices are applicable to only a relatively narrow range of conditions, a fact which often limits the applicability of any single $P$ Index to a single state. Models have wider applicability because they can account for very diverse climate, management, topography, and soil factors. In addition, the development of separate $\mathrm{P}$ Indices for each state appears to be an unnecessary duplication of effort. The collection of field data in each state necessary to validate individual $\mathrm{P}$ Indices is extremely expensive. There is a tremendous amount of field-scale $\mathrm{P}$ data which have already been collected. Harmel et al. (2006) found more than 1,100 watershed years of field-scale data in the published literature alone. Most models are not regionally specific, and thus these existing data can be used to perform a comprehensive validation for a nationwide quantitative $\mathrm{P}$ index. It is likely that any national $\mathrm{P}$ management tool will require a process-based hydrologic model at its core.

\section{LITERATURE CITED}

Ancev, T., A.L. Stoecker, D.E. Storm, and M.J. White, 2006. The Economics of Efficient Phosphorus Abatement in a Watershed. Journal of Agricultural and Resource Economics 31(3):529-548.

Arnold, J.G., R. Srinivasan, R.S. Muttiah, and J.R. Williams, 1998. Large Area Hydrologic Model Development and Assessment Part 1: Model Development. Journal of the American Water Resources Association 34(1):73-89.

ASAE (American Society of Agricultural Engineers), 1995. Manure Production and Characteristics. American Society of Agricultural Engineers. Standards D384.1. Agricultural Engineering Yearbook. ASAE, St. Joseph, Michigan.

Birr, A.S. and D.J. Mulla, 2001. Evaluation of the Phosphorus Index in Watersheds at the Regional Scale. Journal of Environmental Quality 30(6):2018-2025.

Edwards, D.R., T.C. Daniel, J.F. Murdoch, and P.A. Moore, 1996. Quality of Runoff From Four Northwest Arkansas Pasture Fields Treated With Organic and Inorganic Fertilizer. Transactions of the ASAE 39(5):1689-1696.

Edwards, D.R., T.C. Daniel, J.F. Murdoch, P.F. Vendrell, and D.J. Nichols 1994. The Moore's Creek Monitoring Project. Arkansas Soil and Water Conservation Commission, Little Rock, Arkansas.

Eghball, B. and J.E. Gilley, 2001. Phosphorus Risk Assessment Index Evaluation Using Runoff Measurements. Journal of Soil and Water Conservation 56(3):202-206.

Franzluebbers, A.J., J.A. Stuedemann, and S.R. Wilkinson, 2002. Bermudagrass Management in the Southern Piedmont USA. II. Soil Phosphorus. Soil Science Society of America Journal 66(1):291-298.

Gassman, P.W., M.R. Reyes, C.H. Green, and J.G. Arnold, 2007. The Soil and Water Assessment Tool: Historical Development, Applications and Future Research Directions. Transactions of the ASABE 50(4):1211-1250.

Haggard, B., D. Storm, R. Tejral, Y. Popova, V. Keyworth, and E. Stanley, 2001. Stream Nutrient Retention in Three Northeastern Oklahoma Agricultural Catchments. Transactions of the ASAE 44(3):597-605.

Harmel, D., S. Potter, P. Ellis, K. Reckhow, and C. Green, 2006. Compilation of Measured Nutrient Load Data for Agricultural Land Uses in the United States. Journal of the American Water Resources Association 42(5):1163-1178.

Harmel, R.D., H.A. Torbert, P.B. DeLaune, B.E. Haggard, and R.L. Haney, 2005. Field Evaluation of Three Phosphorus Indices on New Application Sites in Texas. Journal of Soil and Water Conservation 60(1):29-42.

Lemunyon, J.L. and R.G. Gilbert, 1993. The Concept and Need for a Phosphorus Assessment Tool. Journal of Production Agriculture 6:483-486. 
NRCS (Natural Resource Conservation Service), 1994. The Phosphorus Index a Phosphorus Assessment Tool. United States Department of Agriculture, Natural Resources Conservation Service. http://www.nrcs.usda.gov/TECHNICAL/ECS/nutrient/pindex. html, accessed on December 31, 2008.

Pierson, S.T., M.L. Cabrera, G.K. Evanylo, H.A. Kuykendall, C.S Hoveland, M.A. McCann, and L.T. West, 2001. Phosphorus and Ammonium Concentrations in Surface Runoff from Grasslands Fertilized with Broiler Litter. Journal of Environmental Quality 30(5):1784-1789.

Popova, Y., V. Keyworth, B. Haggard, and D. Storm, 2006. Stream Nutrient Limitation and Sediment-Interactions in the EuchaSpavinaw Basin. Journal of Soil and Water Conservation Society $61(2): 105-115$.

Redmon, L.A., and T.G. Bidwell 1997. Stocking Rate: The Key to Successful Livestock Production. Oklahoma Cooperative Extension Service Fact Sheet F-2871. http://www.okrangelandswest.okstate.edu/pdfFiles/OSUextPubs/F-2871.pdf, accessed on December 31, 2008.

Schindler, D., 1978. Factors Regulating Phytoplankton Production and Standing Crop in the World's Freshwaters. Limnology and Oceanography 23(3):478-486.

Sharpley, A., 1999. Agricultural Phosphorus, Water Quality, and Poultry Production: Are They Compatible? Poultry Science 78(5):660-673.

Sharpley, A.N., T. Daniel, T. Sims, J. Lemunyon, R. Stevens, and R. Parry, 2003a. Agricultural Phosphorus and Eutrophication (Second Edition). U.S. Department of Agriculture, Agricultural Research Service, University Park, Pennsylvania.

Sharpley, A., P. Kleinman, R. McDowell, and M. Gitau, 2002. Modeling Phosphorus Transport in Agricultural Watersheds: Processes and Possibilities. Journal of Soil and Water Conservation 57(6):425-440.

Sharpley, A.N., R.W. McDowell, J.L. Weld, and P.J.A. Kleinman, 2001. Assessing Site Vulnerability to Phosphorus Loss in an Agricultural Watershed. Journal of Environmental Quality 30(6):2026-2036.

Sharpley, A.N., J.L. Weld, D.B. Beegle, and P.J.A. Kleinman, 2003b. Development of Phosphorus Indices for Nutrient Management Planning Strategies in the United States. Journal of Soil and Water Conservation 58(3):137-152.

Storm, D.E., M.J. White, and M.D. Smolen 2002. Modeling the Lake Eucha Basin Using SWAT 2000. Oklahoma State University, Biosystems and Agricultural Engineering Department. http://storm.okstate.edu/eucha/modeling/Eucha_OSU_2002_SWAT 2000.pdf, accessed January 7, 2008.

Tilman, D., S.S. Kilham, and P. Kilham, 1982. Phytoplankton Community Ecology: The Role of Limiting Nutrients. Annual Review of Ecology and Systematics 13(1):349-372.

USEPA (United States Environment Protection Agency). 2008. National Section 303(d) List Fact Sheet. United States Environmental Protection Agency. http://iaspub.epa.gov/waters/ national_rept.control, accessed on December 31, 2008.

Vadas, P.A., W.J. Gburek, A.N. Sharpley, P.J.A. Kleinman, P.A. Moore, Jr., M.L. Cabrera, and R.D. Harmel, 2007. A Model for Phosphorus Transformation and Runoff Loss for SurfaceApplied Manures. Journal of Environmental Quality 36(1):324332.

Vadas, P.A., T. Krogstad, and A.N. Sharpley, 2006. Modeling Phosphorus Transfer Between Labile and Nonlabile Soil Pools: Updating the EPIC Model. Soil Science Society of America Journal 70(3):736-743.

Veith, T., A. Sharpley, J. Weld, and W. Gburek, 2005. Comparison of Measured and Simulated Phosphorus Losses With Indexed Site Vulnerability. Transactions of the ASAE 48(2):557-565.

White, K.L. and I. Chaubey, 2005. Sensitivity Analysis, Calibration, and Validations for a Multisite and Multivariable SWAT
Model. Journal of the American Water Resources Association 41(5):1077-1089.

White, M., 2007. Development and Validation of a Quantitative Phosphorus Loss Assessment Tool. Ph.D. Dissertation, Oklahoma State University, Stillwater, Oklahoma.

White, M., D. Storm, T. Demissie, H. Zhang, and M. Smolen 2003. Pasture Phosphorus Management (PPM) Calculator Technical Documentation Version 1.0. Division of Agricultural and Natural Resources, Oklahoma State University. http://biosystems. okstate.edu/home/dstorm/PPM_Calculator/PPM\%20Calculator\% 20Version\%201.0\%20documentation\%2012-31-2003.pdf, accessed on April 14, 2008.

Williams, J., 1975. Sediment Routing for Agricultural Watersheds. Water Resources Bulletin 11(5):965-974.

Williams, J.R., 1990. The Erosion-Productivity Impact Calculator (EPIC) Model: A Case History. Philosophical Transactions: Biological Sciences 329:421-428.

Young, R.A., C.A. Onstad, D.D. Bosch, and W.P. Anderson, 1989. AGNPS: A Nonpoint-Source Pollution Model for Evaluating Agricultural Watersheds. Journal of Soil and Water Conservation 44(2):168-173. 